TUTUT SISWATI, SRI REZEKI, AULIA STHEPHANI, LILIS MARINA ANGRAINI

Development Student Worksheet Based on Problem-Based Learning (PBL)

\title{
Development Student Worksheet Based on Problem-Based Learning (PBL) on Matrix Materials for Class XI
}

\author{
Tutut Siswati*, Sri Rezeki, Aulia Sthephani, Lilis Marina Angraini \\ Program Studi Pendidikan Matematika, Universitas Islam Riau, Indonesia \\ *tututsiswati@student.uir.ac.id
}

\begin{abstract}
ABSTRAK
Penelitian ini memiliki tujuan untuk mengetahui kevalidan LKPD berbasis PBL pada matriks kelas XI. Jenis penelitian yang digunakan adalah metode penelitian dan pengembangan (Research and Development). Tahapan penelitian ini, akan berdasar pada tahapan pengembangan ADDIE yang terdiri dari tahap analisis (analisys), desain (design), dan pengembangan (development). Instrumen yang digunakan dalam penelitian ini berupa lembar validasi LKPD, dan data yang diperoleh akan diolah secara deskriptif. Dari hasil penelitian didapatkan jika hasil validasi LKPD 87,92\% dengan kategori sangat valid. Hasil Berdasarkan akhir penelitian ini, maka diperoleh Lembar Kerja Peserta Didik Berbasis Problem Based Learning (PBL) pada Materi Matriks Kelas XI yang sangat valid.
\end{abstract}

Kata kunci: LKPD, Pengembangan, Problem Based Learning, Validitas

\begin{abstract}
This study aims to determine the validity of PBL-based worksheets on the XI class matrix material. The type of research used is the research and development method $(\mathrm{R} \& \mathrm{D})$. This research stage will be based on the ADDIE development stage which consists of the analysis, design, and development stages. The instrument used in this research is the LKPD validation sheet, and the data obtained will be processed descriptively. From the research results, it is known that the results of the LKPD validation are $87.92 \%$ with a very valid category. Based on the final results of this study, the Problem Based Learning (PBL) Worksheet on Class XI Matrix Material is very valid.
\end{abstract}

Key words: Development, Problem Based Learning, Student Worksheet, Validity

Received: 2021-09-24

/ Accepted: 2021-11-04

/ Published: 2021-11-15

\section{Introduction}

The Covid-19 pandemic has had an impact on various fields of life, education is one of the areas affected by this pandemic. In this regard, the government has issued a policy so that the learning process is carried out from home or online to prevent the spread of the Covid-19 virus (Trisniawati et al., 2021). The online learning system is implemented to comply with the rules of social distancing and physical distancing (Syarifudin, 2020). In the implementation of online learning activities, innovation is needed so that students continue to play an active role in the learning process (Susanti \& Suripah, 2021).

One of the subjects that require innovation in online learning activities is mathematics. This is because the learning materials for mathematic are importantly related to daily life (Suripah \& Retnawati, 2019). Mathematics needs to be studied by all elements of society because it can be a means of (1) solving problems related to life, (2) practicing logical, clear, and critical thinking skills (Suripah \& Sthephani, 2017), (3) basic science to study other fields of education (Mahmudah, 2018). Mathematics needs to be studied by all students to equip students to be able to think logically, critically, and systematically (Simorangkir \& Sembiring, 2018: 29).

However, most students are still reluctant to learn mathematics. Some of them still think that mathematical concepts are abstract, and difficult to understand (Novitasari, 2016). In addition, during the online learning process, there are still many teachers who lack understanding in choosing learning methods and media, thus making it increasingly difficult for students to understand mathematics learning materials (Yulfitri et al., 2019).

92 | $\begin{aligned} & \text { C2021 by Department of Mathematics Education, UMP, Purwokerto, Indonesia } \\ & \text { p-ISSN 2477-409X, e-ISSN: 2549-9084 and website: http://jurnal nasional.ump.ac.id/index.php/alphamath/ }\end{aligned}$ 
In online learning activities, the learning model that can be applied by teachers is Problem Based Learning (PBL). The PBL model consists of presenting the context of the problem so that it can help students to think in stages (Purnomo, 2020). In addition, with the context of presenting the problem, will train students to be more confident, persistent, and able to think flexibly by exploring mathematical ideas, to increase students' enthusiasm in learning mathematics and their mathematical communication skills (Situmorang et al., 2015).

Mathematics learning material that can be applied using the PBL method is Matrix material. This is because the matrix material plays an important role in everyday life. The matrix is a material whose concept has principles in operation. The concept of matrix material is related to real problems that come from facts so that the concept of matrix material can be found in solving everyday problems (Purwati et al., 2018). One of the uses of matrix material is to solve various mathematical problems related to linear equations and linear transformations. In everyday life, the matrix can facilitate the process of analyzing economic problems with several variables. Therefore, it is necessary to develop innovations, one of which is learning tools in a matrix material.

Learning tools are an important guide for teachers that must be prepared before starting learning activities (Masitah, 2018). Learning tools can be a guide for teachers to conveying knowledge to students, and with learning tools, the learning process becomes more systematic and can achieve optimal goals (Purnamasari \& Nur Wangid, 2016). According to (Rando, 2017) In his research, it was found that with the existence of learning tools, the academic potential and social potential of students were more developed by following per under curriculum achievements.

One of the learning tools that can help students' learning process is student worksheets. Student worksheets can direct students to learn independently and can be designed with certain learning methods such as PBL which will help reasoning abilities so that they can find various alternative solutions and can carry out the problem identification process (Wahyuni \& Miterianifa, 2019). In working on matrix problems, there are still many mistakes made by students when solving problems. This is because the context of the matrix material consisting of groups of numbers arranged according to rows and columns in a rectangular form is difficult for students to understand. Therefore, the concept of matrix learning related to everyday life can be applied to the student worksheets with the PBL learning method.

This research will develop a learning tool in the form of a Student Worksheet based on Problem Based Learning (PBL). In Problem Based Learning (PBL)-based Student Worksheet, consisting of subject matter, questions, activities, information, and teaching stages, students follow the following steps, namely: problem orientation, organizing student learning systems, guiding investigations both individually and in groups, developing and presenting the work, and analyzing and evaluating the problem-solving process (Sofyan and Kokom, 2016). The advantages of PBL include: 1) Encouraging students to have problem-solving skills related to real situations, 2) helping students to increase knowledge independently through the learning process, 3) learning materials will be related to real problems so that students can understand the problem (Dirgatama et al., 2016).

This research has a purpose to find out the validity of the Student Worksheet Based on Problem Based Learning (PBL) on the Matrix material for Class XI SMK. As for this research for several parties, among others: (1) for educators, it can provide an alternative math-based worksheets 
TUTUT SISWATI, SRI REZEKI, AULIA STHEPHANI, LILIS MARINA ANGRAINI

Development Student Worksheet Based on Problem-Based Learning (PBL)

Problem Based Learning (PBL) on the matrix material, (2) for students, this research will be able to develop the potential of students to become active, creative and innovative students in terms of problem-solving, (3) for schools, this research is useful for additional learning tools and sources of information in making Student Worksheet that by following per under the 2013 Curriculum Standards, (4) for researchers, so that this research can add knowledge and insight in developing -based Student Worksheet Problem Based Learning (PBL) on the matrix material for class XI SMK.

\section{Methods}

The method in this study will refer to the ADDIE development stage which consists of 3 stages namely analysis, design, and development (Mulyatiningsih, 2011). This research will focus on the development stage with the initial step of analyzing problems and needs, after that conducting a literature study to create a learning concept and the final stage of designing learning tools and worksheets. At the development stage, the researcher will test the effectiveness of the resulting product (Sugiyono, 2019).

The research was conducted on the campus of the Islamic University of Riau (UIR) Faculty of Teacher Training and Mathematics Education (2 lecturers as validators) which is located at Jalan Kaharuddin Nasution, Pekanbaru City, and the Integrated Agricultural Vocational School of Prov. Riau (1 teacher as validator) whose address is at Jalan Kaharuddin Nasution, Maharatu, Marpoyan Damai District, Pekanbaru City. The research was carried out in the 2021/2022 academic year in odd semesters. The object of this research is a mathematics learning device, namely the Student Worksheet (LKPD) based on Problem Based Learning (PBL) on the Matrix material in class XI.

In this study, researchers will use data collection techniques by calculating the assessment score for each aspect of the assessment filled out by the validator. The assessment scores in this study are the Guttman scale and the Likert scale. The Guttman scale is a measurement scale consisting of 2 choices as yes and no, true or false, never and never, positive or negative, and others (Sugiyono, 2019). The Guttman scale is usually used by researchers to obtain absolute answers to a phenomenon or problem. Guttman scale presentation can be in the form of multiple-choice or the form of a checklist. In this study the presence of the scale is in the form of a checklist, if the validation sheet is worth 1, then it is categorized as Yes or Agree. And if the validation sheet is 0 , then it is categorized as No or Disagree. The highest score on the choice of the Guttman scale is 1 and the lowest is 0 . The analysis technique will be carried out as in the Likert scale.

Table 1. Validation Sheet Assessment Category (Guttman Scale)

\begin{tabular}{ccc}
\hline No & Rating Score & Category \\
\hline 1 & 0 & No/Disagree \\
2 & 1 & Yes agree \\
\hline
\end{tabular}

Source: Modification (Sugiyono, 2019)

The Likert scale is usually used by researchers to measure attitudes, as well as individual or group opinions regarding a problem or phenomenon (Sugiyono, 2019). The assessment score on the Likert scale, there are two positive choices and the other two negative choices. To avoid doubtful or neutral answers, the researcher modified the Likert scale by removing the neutral criteria. So that the validation sheet has a value of 4 which is categorized as very good, a value of 3 is categorized as good, a value of 2 is categorized as poor, and a value of 1 is categorized 
as very poor. The instrument in this study is a non-test instrument, namely a validation sheet with a modified assessment category fromSugiyono (2019) as follows:

Table 2. Validation Sheet Assessment Category (Likert Scale)

\begin{tabular}{cc}
\hline Rating Score & Criteria \\
\hline 4 & Very Good (SB) \\
3 & Good (B) \\
2 & Less (K) \\
1 & Very Poor (SK) \\
\hline
\end{tabular}

The research data, the researcher will analyze descriptively which later the data will be able to give an overview of the object quantitatively. The process of descriptive data analysis is carried out to obtain an initial description of the data that has been collected (Sholikhah, 2016). The data that has been obtained will be analyzed descriptively to get an initial description of the gains obtained on these values. The use of descriptive data analysis depends on the type of data to be analyzed.

Descriptively, the level of validity on the Student Worksheet can be calculated using the formula (Akbar, 2017) as follows:

$$
\begin{aligned}
V_{a 1} & =\frac{T S e}{T S h} \times 100 \% \\
V_{a 2} & =\frac{T S e}{T S h} \times 100 \% \\
V_{a 3} & =\frac{T S e}{T S h} \times 100 \%
\end{aligned}
$$

After getting the results of the validation test from the experts, the next step is to calculate the combined validation with the following formula:

Information:

$$
V=\frac{v_{\mathrm{a} 1}+v_{\mathrm{a} 2}+v_{\mathrm{a} 3}}{3}=\cdots \%
$$

$\mathrm{V}=$ Validation score (combined)

$V a_{1}=$ Validation result score from expert 1

$V a_{2}=$ Score of validation results from experts 2

$V a_{3}=$ Score of validation results from experts 3

$\mathrm{TSh}=$ Total expected maximum score (ideal maximum score)

$\mathrm{TSe}=$ Total empirical score (validation result from validator)

After receiving a validation assessment from the experts, the next step is to calculate the combined validation. Then, after knowing the combined validation average score, the percentage level of validity can be adjusted according to the assessment category according to (Akbar, 2017) as follows (table 3):

Table 3. Product Validity Level Criteria

\begin{tabular}{ccc}
\hline No & Validity Criteria & Validity Level \\
\hline 1 & $85.01 \%-100.00 \%$ & Very valid \\
\hline
\end{tabular}


TUTUT SISWATI, SRI REZEKI, AULIA STHEPHANI, LILIS MARINA ANGRAINI

Development Student Worksheet Based on Problem-Based Learning (PBL)

\begin{tabular}{ccc}
\hline No & Validity Criteria & Validity Level \\
\hline 2 & $70.01 \%-85.00 \%$ & Quite Valid \\
3 & $50.01 \%-70.00 \%$ & Not valid \\
4 & $01.00 \%-50.00 \%$ & Invalid \\
\hline
\end{tabular}

\section{Results and Discussion}

The discussion in this study is about the description or explanation of each stage of the LKPD development process and the presentation of data from the validation results of experts. This LKPD was developed with 3 stages of ADDIE development, namely analysis, design, and development (Mulyatiningsih, 2011).

In the initial step, namely analysis, three initial stages must be carried out to obtain information about the problem namely needs analysis, material analysis, and student analysis. In the needs analysis stage, the researcher interviewed Mr. Jose Bonatua Hasibuan, S. Pd., M. Si., as a teacher of Integrated Agriculture Vocational School of Prov. Riau aims to obtain information related to the characteristics of students, the learning process in the classroom, and the methods used by teachers during the learning process. Material analysis needs to be considered, where the selection of this material is based on previous research which states that the matrix is learning material in which the context of the material is related to problems that students often encounter, but $60 \%$ of the 27 students have not been able to understand the material because the context is considered difficult. From the results of interviews with teachers of mathematics subjects $60 \%$ of students have not been actively involved in learning.

Design stage the researcher will design the device developed, namely the Student Worksheet. Student Worksheet will be made based on the context of the lesson plans that have been made by researchers. Student Worksheet is developed with activities that can support students' activities to get information. Before the Student Worksheet is designed, the researcher first prepares the material to be taught and makes designs with attractive colors and will be made according to the Problem Based Learning (PBL) learning model. The stages contained in the Student Worksheet with the Problem Based Learning (PBL) model are orienting students to problems, organizing students to learn, guiding individuals or groups, developing and presenting work, and analyzing and evaluating the problem-solving process. In addition to Student Worksheet conducted at the design stage, researchers also designed research instruments.

The next stage is development. In the development process, an expert assessment will be carried out, namely through a validation test that will be carried out by a competent validator. The validators will provide an assessment of the Student Worksheet that has been developed by the researcher. The test results are then used for revision so that the Student Worksheet meets the requirements for testing. Because during the Covid-19 pandemic, learning is done online, so the Student Worksheet is only tested by validators. To see one of the Student Worksheet designs designed by researchers, it can be seen in the following picture: 


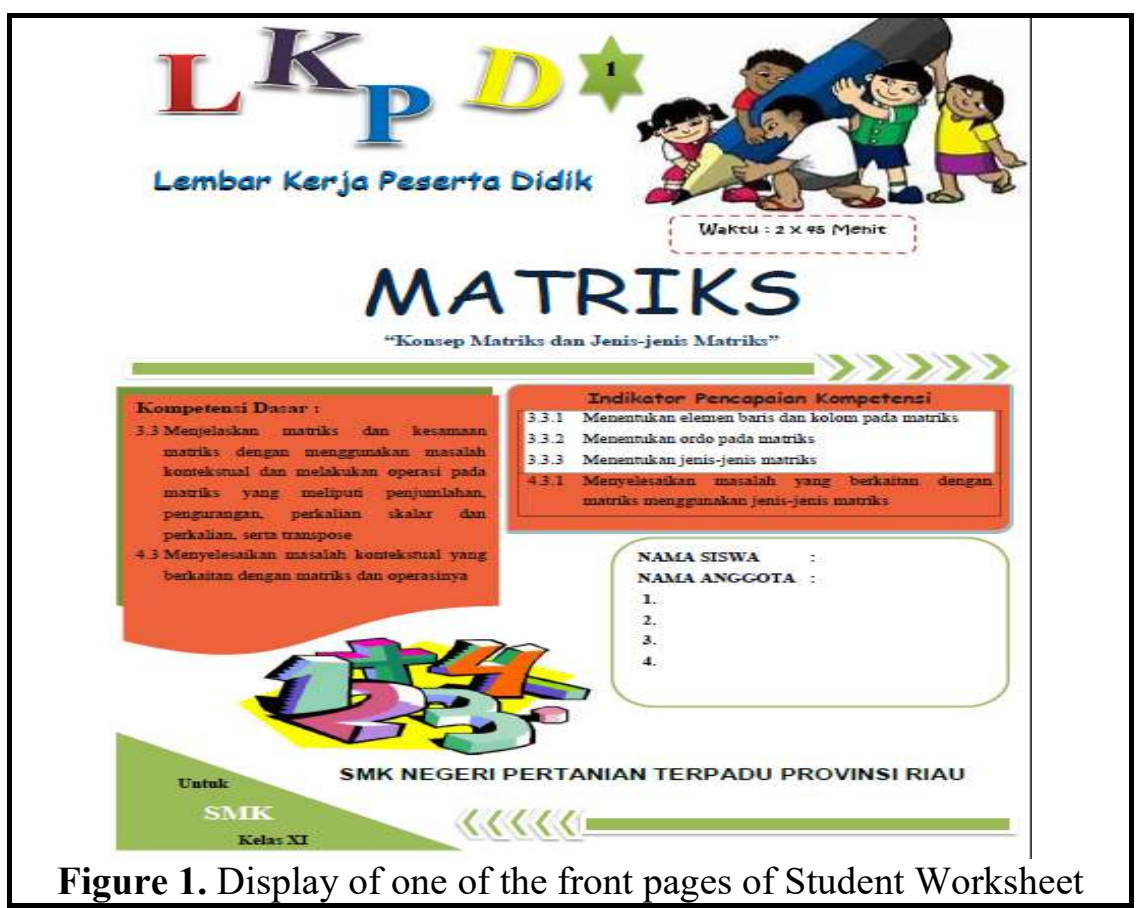

Figure 1 above is the front cover design of the Student Worksheet made by the researcher. Where there are subject titles, Basic Competencies (KD), Competency Achievement Indicators (GPA), student names, education level, and school name.

Result of evaluation the three validators of the Student Worksheet that the researcher has developed in terms of the assessed aspects are as follows:

Table 4. Percentage of Student Worksheet Validation Sheet Criteria in terms of Aspects Assessed by Validators 1

\begin{tabular}{llcccc}
\hline & & \multicolumn{4}{c}{ LKPD-1 - LKPD-3 } \\
\cline { 2 - 5 } No & Rated aspect & SE & $\begin{array}{c}\text { high } \\
\text { school }\end{array}$ & RP (\%) & TV \\
\hline 1. & Content aspect & 16 & 21 & 76.19 & Quite Valid \\
2. & Didactic aspect & 12 & 16 & 75 & Quite Valid \\
3. & Construction aspect & 18 & 20 & 90 & Very Valid \\
4. & Technical aspects & 15 & 20 & 75 & Quite Valid \\
5. & Time aspect & 1 & 4 & 25 & Invalid \\
\hline
\end{tabular}

In the Table 4, it can be seen that the content aspect scored $76.19 \%$, the didactic aspect scored $75 \%$, the construction aspect scored $90 \%$, the technical aspect received a score of $75 \%$ and the time aspect is the time aspect. Which has the lowest score with an acquisition of $25 \%$. This is because there are a few errors and discrepancies that lie in the work of the Student Worksheet.

Table 5. Percentage of Student Worksheet Validation Sheet Criteria in terms of Aspects Assessed by Validators 2

\begin{tabular}{llcccc}
\hline \multirow{2}{*}{ No } & \multirow{2}{*}{ Rated aspect } & \multicolumn{4}{c}{ LKPD-1 - LKPD-3 } \\
\cline { 3 - 5 } & & SE & high school & RP (\%) & TV \\
\hline 1. & Content aspect & 19 & 21 & 90.47 & Very Valid \\
\hline
\end{tabular}


TUTUT SISWATI, SRI REZEKI, AULIA STHEPHANI, LILIS MARINA ANGRAINI

Development Student Worksheet Based on Problem-Based Learning (PBL)

\begin{tabular}{llcccc}
\hline \multirow{2}{*}{ No } & \multirow{2}{*}{ Rated aspect } & SE & high school & RP (\%) & TV \\
\cline { 2 - 5 } & & 14 & 16 & 87.5 & Very Valid \\
\hline 2. & Didactic aspect & 17 & 20 & 85 & Quite Valid \\
3. & Construction aspect & 17 & 20 & 85 & Quite Valid \\
4. & Technical aspects & 17 & 4 & 100 & Very Valid \\
5. & Time aspect & 4 & &
\end{tabular}

In the table 5, it can be seen that the construction and technical aspects are the lowest scores with a score of $85 \%$. This is because there are still errors and inconsistencies in the Student Worksheet.

Table 6. Percentage of Student Worksheet Validation Sheet Criteria Judging from Aspects Assessed by Validators 3

\begin{tabular}{llcccccccc}
\hline & & \multicolumn{3}{c}{ LKPD-1 - LKPD-2 } & \multicolumn{3}{c}{ LKPD-3 } \\
\cline { 2 - 8 } No & Rated aspect & SE & $\begin{array}{c}\text { high } \\
\text { school }\end{array}$ & $\begin{array}{c}\text { RP } \\
(\%)\end{array}$ & TV & SE & $\begin{array}{c}\text { high } \\
\text { school }\end{array}$ & $\begin{array}{c}\text { RP } \\
(\%)\end{array}$ & TV \\
\hline 1. & $\begin{array}{l}\text { Content } \\
\text { aspect }\end{array}$ & 21 & 21 & 100 & $\begin{array}{c}\text { Very } \\
\text { Valid }\end{array}$ & 21 & 21 & 100 & $\begin{array}{c}\text { Very } \\
\text { Valid }\end{array}$ \\
2. & $\begin{array}{l}\text { Didactic } \\
\text { aspect }\end{array}$ & 16 & 16 & 100 & $\begin{array}{c}\text { Very } \\
\text { Valid }\end{array}$ & 15 & 16 & 93.75 & $\begin{array}{c}\text { Very } \\
\text { Valid }\end{array}$ \\
3. & $\begin{array}{l}\text { Construction } \\
\text { aspect }\end{array}$ & 20 & 20 & 100 & $\begin{array}{c}\text { Very } \\
\text { Valid }\end{array}$ & 20 & 20 & 100 & $\begin{array}{l}\text { Quite } \\
\text { Valid }\end{array}$ \\
4. & $\begin{array}{l}\text { Technical } \\
\text { aspects }\end{array}$ & 20 & 20 & 100 & $\begin{array}{c}\text { Very } \\
\text { Valid }\end{array}$ & 20 & 20 & 100 & $\begin{array}{l}\text { Quite } \\
\text { Valid } \\
\text { 5. }\end{array}$ \\
Time aspect & 4 & 4 & 100 & $\begin{array}{c}\text { Very } \\
\text { Valid }\end{array}$ & 4 & 4 & 100 & $\begin{array}{l}\text { Very } \\
\text { Valid }\end{array}$ \\
\hline
\end{tabular}

In the Table 6, it can be seen that the didactic aspect is the aspect with the lowest score, which is $93.75 \%$. This is because there are still errors and discrepancies in the conclusions in Student Worksheet to 3 .

Table 7. Results of Student Worksheet Validation Analysis

\begin{tabular}{lccccc}
\hline \multirow{2}{*}{ LKPD } & \multicolumn{3}{c}{ Validation Percentage (\%) } & \multirow{2}{*}{ Average (\%) } & \multirow{2}{*}{ Validation Level } \\
\cline { 2 - 4 } & V1 & V2 & V3 & & \\
\hline LKPD-1 & 76.54 & 87.65 & 100 & 88.06 & Very Valid \\
LKPD-2 & 76.54 & 87.65 & 100 & 88.06 & Very Valid \\
LKPD-3 & 76.54 & 87.65 & 98.76 & 87.65 & Very Valid \\
Total Average (\%) & & & 87.92 & Very Valid \\
\hline
\end{tabular}

Based on previous research conducted by (Purwati et al., 2018) recapitulation of validation results by experts, namely material experts, design experts, and media experts. The results of the validation by these experts on table 7 showed that the Problem Based Learning (PBL)-based Student Worksheet was in the proper category, very feasible with the percentages of $88.06 \%$, $88.06 \%$, and $87.65 \%$. Compared with the research conducted by the current researcher, seen from the results of the validation by material experts, the percentage of $87.92 \%$ of Problem Based Learning (PBL)-based Student Worksheet conducted by researchers is categorized as very valid. And the developed learning worksheets are feasible to use. 


\section{Conclusion}

From the results of data analysis, the conclusion is obtained, namely the mathematics learning device in the form of Student Worksheet with the Problem Based Learning (PBL) learning model on the matrix material for class XI SMK which has been tested for validity. The results of the Student Worksheet validation analysis with an average score of $87.92 \%$ with a very valid validation level and feasible to be tested on high school or vocational high school students as considered and assessed by expert validators.

\section{References}

Akbar, S. (2017). Instrumen Perangkat Pembelajaran. In Bandung: PT. Reamaja Rosdakarya.

Dirgatama, C. H. A., Th, D. S., \& Ninghardjanti, P. (2016). Penerapan Model Pembelajaran Problem Based Learning Dengan Mengimplementasi Program Microsoft Excel Untuk Meningkatkan Keaktifan Dan Hasil Belajar Mata Pelajaran Administrasi Kepegawaian Di Smk Negeri 1 Surakarta. Jurnal Informasi Dan Komunikasi Administrasi Perkantoran, 1(1), 36-53. https://jurnal.uns.ac.id/JIKAP/article/view/19138

Mahmudah, R. (2018). Pengembangan Media Pembelajaran Matematika Dengan Menggunakan Software Lectora Inspire Pada Materi Perbandingan untuk Siswa Kelas VII SMP. Journal of Honai Math, 1(1), 1-13.

Masitah. (2018). Pengembangan Perangkat Pembelajaran untuk Memfasilitasi Guru Menumbuhkan Rasa Tangung Jawab Siswa SD terhadap Masalah Banjir. Proceeding Biology Education Conference, 15(1), 40-44.

Mulyatiningsih, E. (2011). Riset Terapan Bidang Pendidikan dan Teknik. In Yogyakarta: UNY Press.

Novitasari, D. (2016). Pengaruh Penggunaan Multimedia Interaktif Terhadap Kemampuan Pemahaman Konsep Matematis Siswa. FIBONACCI: Jurnal Pendidikan Matematika Dan Matematika, 2(2), 8. https://doi.org/10.24853/fbc.2.2.8-18

Purnamasari, V., \& Nur Wangid, M. (2016). Pengembangan Perangkat Pembelajaran Berbasis Scientific Approach Untuk Membangun Karakter Kepedulian Dan Kedisiplinan. Jurnal Pendidikan Karakter, 6(2), 167-180. https://doi.org/10.21831/jpk.v6i2.12047

Purnomo, E. A. (2020). Implementasi Lesson Study Melalui Model Pembelajaran Problem Based Learning Materi Spltv Kelas X Iik. AlphaMath : Journal of Mathematics Education, 6(1), 36. https://doi.org/10.30595/alphamath.v6i1.7619

Purwati, Y., Buyung, \& Relawati. (2018). Pengembangan Lembar Kerja Siswa (LKS) Berbasis Problem Based Learning (PBL) pada Materi Matriks Siswa Kelas XI MIA SMAN 6 Kota Jambi. Jurnal Ilmiah Dikdaya, 8(1).

Rando, A. R. (2017). Pengembangan Perangkat Pembelajaran dalam Implementasi Strategi Contextual Teaching Learning untuk Meningkatkan Hasil Belajar IPS Pokok Bahasan Perkembangan Teknologi pada Siswa Kelas IV SD. Jurnal Pendidikan (Teori Dan Praktik), 1(1), 1. https://doi.org/10.26740/jp.v1n1.p1-12

Sholikhah, A. (2016). Statistik Deskriptif dalam Penelitian Kualitatif. Komunika, 10(2), 342.

Simorangkir, F. M. A., \& Sembiring, R. K. B. (2018). Peningkatan Kemampuan Number Sense Siswa Melalui Media Pembelajaran Matematika Berbantuan Software Lectora Inspire. MES: Journal of Mathematics Education and Science, 4(1), 29-35. https://doi.org/10.30743/mes.v4i1.866

Situmorang, A. N., Abdurrahman, \& Wahyuni, R. (2015). Pengembangan Lembar Kerja Siswa (LKS) dengan Metode Penemuan Terbimbing pada Materi Segiempat Kelas VII SMP Negeri 4 Pekanbaru. AKSIOMATIK: Jurnal Penelitian Pendidikan Dan Pembelajaran Matematika, 3(3). 
Sugiyono. (2019). Metode Penelitian Kuantitatif, Kualitatif, dan R\&D. In Bandung: Alfabeta. Suripah, \& Retnawati, H. (2019). Student Mathematical Connection Ability in Representing Multiplication at the Elementary School. Journal of Physics: Conference Series, 1254(1). https://doi.org/10.1088/1742-6596/1254/1/012080

Suripah, S., \& Sthephani, A. (2017). Kemampuan berpikir kreatif matematis mahasiswa dalam menyelesaikan akar pangkat persamaan kompleks berdasarkan tingkat kemampuan akademik. Pythagoras: Jurnal Pendidikan Matematika, 12(2), 149-160. https://doi.org/10.21831/pg.v12i2.16509

Susanti, W. D., \& Suripah. (2021). Efektivitas Website sebagai Media Pembelajaran Matematika Selama Masa Pembelajaran Daring. Edumatica: Jurnal Pendidikan Matematika, 11(April), 73-83. https://doi.org/10.22437/edumatica.v11i01.12225

Syarifudin, A. S. (2020). Implementasi Pembelajaran Daring untuk Meningkatkan Mutu Pendidikan sebagai Dampak Diterapkannya Social Distancing. Jurnal Pendidikan Bahasa Dan Sastra Indonesia, 5(1), 31-34.

Trisniawati, T., Muanifah, M. T., Rhosyida, N., \& Hidayat, R. A. (2021). Eksplorasi Hasil Belajar Matematika melalui Penerapan Sistem Pembelajaran Daring (SIPEDAR) di Masa Pandemi Covid-19. AlphaMath: Journal of Mathematics Education, 7(1), 57. https://doi.org/10.30595/alphamath.v7i1.10195

Wahyuni, A. S., \& Miterianifa, M. (2019). Desain Lembar Kerja Peserta Didik Berbasis Problem Based Learning Untuk Meningkatkan Self-Efficacy Peserta Didik. JTK (Jurnal Tadris Kimiya), 4(1), 78-90. https://doi.org/10.15575/jtk.v4i1.4240

Yulfitri, Haji, S., \& Nirwana. (2019). Pengaruh Model Pembelajaran Pencapaian Konsep Berbasis Etnomatematika Rejang Lebong Terhadap Kemampuan Pemecahan Masalah Matematika. Jurnal Pendidikan Matematika Raflesia, 04(02), 76-85. https://ejournal.unib.ac.id/index.php/jpmr\%0APengaruh 